\title{
Könyvszemle
}

SIPOS JÚLIA GONDOZÁSÁBAN

\section{AZ ELSŐ TELJES DANTE-KOMMENTÁR A POKOLRÓL}

Impozáns könyvet adott ki a 2004-ben alakult Magyar Dantisztikai Társaság a firenzei költő, Dante Alighieri halálának 700. évfordulójára. Nagy József közremüködésével a Társaság elnöke, a kötet szerkesztője Kelemen János vállalta fel azt a feladatot, hogy Magyarországon első ízben átfogó kommentárt adjon közre az Isteni Szinjáték első részéröl, a Pokolról. A több mint félezer oldalas kötet megjelentetése időszerü volt már a magyar dantisztikában, mert a legújabb hazai és külföldi tudományos eredményeket figyelembe véve sorról sorra elemzi e münek a stílusát, forrásait, értelmét és mondanivalóját. Így pedig - az eddigi magyar kommentárokhoz képest - új szempontokkal képes bővíteni és segíteni az amúgy nem könnyen értelmezhető mủvészi (és filozófiai-morális) alkotás jobb megértését.

Ez a valóban figyelemre méltó mü a Magyar Dantisztikai Társaság (MDT) tagjainak közös erőfeszítése és több mint 15 éves munkája eredményeként jelenhetett meg. Arról van ugyanis szó, hogy a Pokol 34 énekének értelmezését és parafrázisát egy-egy kutató vállalta fel. A szerkesztő Kelemen János mellett szükséges felsorolni azoknak a nevét, akik vállalkoztak erre a feladatra, amire magyar nyelven korábban még nem volt példa: Nagy József (aki a szerkesztésben is közreműködött), Mátyus Norbert, Hoffmann Béla, Tóth Tihamér, Berényi Márk és Draskóczy Eszter. Az így közreadott szöveget sok vita és egyeztetés elózte meg a Társaság ülésein, amelynek a munkájába így az MDT más tagjai is részt vállaltak.

A költő, aki 1265-ben született Firenzében, és majd húszéves száműzetése után 1321-ben Ravennában halt meg, egyik északolasz városból a másikba való vándorlása során ezt a müvét 1306 és 1309 között írta. A probléma ott kezdődik, hogy Dante semmilyen autográf írását sem ismerjük, müveit sokan másolták és adták tovább. Csak a Trecentóból több tucat kódexet ismerünk, ahol Danténak ezt a müvét átírták. A szöveget azóta nagyrészt sikerült helyreállítani, de még ma is vannak benne kisebb filológiai problémák, melyekre e kötetben is találunk magyarázatváltozatokat. Ezek azonban a szöveg értelmét nem módosítják.

Hogyan is épül fel ez a kötet? Először is az egyes énekek gondozói, értelmezöi saját maguk szó szerint fordították le az adott, eredetileg rímes szöveget. Ez lehet vitatható módszer is, de a szerzők szándéka az volt, hogy - eltekintve a rímek- 
től - a maga eredeti formájában adják vissza a költemény szövegét (annyira, hogy szokatlan módon a címben Komédiaként nevezik az azóta már Isteni Szinjátékként ismert mű címét). Jegyezzük meg, hogy olykor ez a fordítás jobban sikerült, mint az eddigi magyar fordítások. Erre jó példa Hoffmann Béla fordítása a Pokol V. énekének nehezen lefordítható utolsó soráról, amit ő így ad vissza: „S elzuhantam, ahogy halottnak teste zuhan el”, az eredeti verssor hangzását utánozva. Azután, minden ének elején olvasható egy rövid tartalmi ismertetés az ének lényegéröl, ami bevezeti az olvasót az elkövetkező történetbe. Ezt követi az ének sorainak részekre osztása, azaz hogy milyen nagyobb logikai egységek találhatóak a szövegben. Ezután jön maga a fordítás, és a legfontosabb szavak, képek, sorok rövidebb-hosszabb magyarázata. A metaforikus, mitológiai, irodalmi, biblikus vagy filozofikus utalások magyarázata rendkívüli felkészültséget igényeltek a szöveg értelmezőjétől. Ráadásul tisztában kellett lennie azokkal a történelmi eseményekkel és személyekkel, akik és amelyek lényegesek annak a kornak az ismeretéhez, amelyeket Dante átélt vagy valamilyen formában utal rájuk. Olyan óriási ismeretanyag található a Pokol szövegeiben, amelyhez más-más értelmezések magyarázatát is szükséges kritikai formában átvenni. Szerencsére a magyar italianisták és dantisták felkészültsége igen kiváló, jól ismerik a régebbi és a legújabb nemzetközi szakirodalmat. Ez tükröződik ebben a nagy ívü kötetben is.

Az egyes sorok fordítása és értelmezése után minden ének végén egy, talán még ennél is lényegesebb Értelmezés található. Ebben az adott ének szerzője vagy szerzői (hiszen néhány éneket többen is jegyeznek) részletesen elmagyarázzák, milyen összefüggések találhatóak az adott énekben, és az hogyan függ össze történetekkel, eseményekkel, emberekkel, valamint a többi énekben található mondanivalóval. Dante ugyanis lépcsőzetesen építette fel művét, szinte matematikai pontossággal, amelynek iránya a földi ember életétől, boldogságvágyától a menynyei boldogság felé tart, amikor majd megpillanthatja Beatricét, és a paradicsomban a visio Dei látomásában részesül. Az értelmezés nehézségét is ez a kettősség adja: vajon a firenzei polgár Dante egykori plátói szerelmét szeretné viszontlátni, vagy a korán elhunyt és a mennybe szállt, az angyalok körében lebegő égi lény iránt sóvárog, mint hívő keresztény. Az értelmezések jellegét ebben a kötetben is az adja meg, hogy miként fogják föl az Isteni Szinjátéknak ezt az üzenetét.

A magyar dantisztika az utóbbi évtizedben úgy tủnik, hogy elhagyja a korábban Kardos Tibor (vagy még korábban Koltay-Kasztner Jenő) által kidolgozott, a müvet evilági értelemben felfogó koncepcióját, és paradigmaváltásba kezdett. Ez a kötet többségében (de nem kizárólagosan) azt az új szellemiséget mutatja, amelynek a lényege az, hogy Dante egyértelmüen középkori és vallásos költő volt, s ekképpen is kell őt értelmezni. Igen, mindkettő igaz, de azzal a megjegyzéssel, hogy a késő középkorban élt Dantéban már a humanizmus bizonyos elemei is megvannak. Ráadásul az Isteni Szinjátékot állandó vándorlása, egyik városból a másikba való (ahogyan maga mondja) gyaloglás vagy lovagolás közben 
gondolhatta ki. Útja során pedig látott északolasz városokat, nyájat terelő juhászt, fenyőligetet, zivatart, vízesést, hegyet-völgyet és más természeti jelenséget, amelyek mind-mind benne vannak a müvében. Ezek teszik teljessé az Isteni Szinjátékot, amely így Dante földi útjának is emléket állít.

Ez összefügg azzal az értelmezési kérdéssel is, hogy vajon az Isteni Szinjáték többféle értelmezési lehetősége közül, amiről maga beszél, a szó szerinti (vagyis evilági) és/vagy az allegorikus a legjelentősebb. A vallásos értelmezést nem hangsúlyozza, mert azt evidensnek veszi. Ez alapján ebben a kötetben az egyes énekeket értelmezők maguk is különböznek egymástól. Míg az első ének szerzői által elemzett énekekben a vallásos/allegorikus momentum a döntő, addig másokéban a poétikai, a költészeti vagy történeti oldal a domináns. Van olyan ének, amelynek az értelmezöje elsősorban a morális aspektusokat emeli ki a költeményben. Egyszóval: ez a kommentár és parafrázis mutatja azt a sokféleséget, amely a dantisztikában itthon és külföldön jellemzi a Dante-kutatásokat, gazdagítva ezzel az értelmezés lehetőségét. Egyúttal azt is érzékeltetve, hogy egyik éneknek sincs, és nem is lehet soha csak egyetlen és kizárólagos értelmezése. A Dante-kutatás így szinte egy végtelen folyamat, amit az eredeti szöveg briliáns sokfélesége idéz elö.

Külön érdeme a kötetnek, hogy kimutatja, Dante milyen forrásokra is támaszkodott, amikor írta az Isteni Szinjátékot. A szerzők minden sornál (!) alapos kutatómunkával, a nemzetközi és hazai szakirodalom segítségével kutatták fel azokat a bibliai forrásokat, azoknak az ókori vagy kortárs szerzőknek munkáit, melyeket Dante ismerhetett, és adott helyeken használt is. Vergiliuson kívül a legtöbbször Statius, Lucanus és Ovidius alkotásainak nyomait fedezik fel benne. Itt azonban egy újabb jelentős problémával találja magát szembe a kommentár készítője (és olvasója): a vándorló, a költeményt útközben író Dante, ő maga, jelen van-e valamilyen formában a költeményben? Erre a szerzők meg is adják a választ: igen. Egyrészt úgy, mint a történet Elbeszélője, másrészt úgy, mint maga is Utazó (sőt mint Költő). De benne van-e maga Dante is, a firenzei számüzött, a maga élettapasztalatával együtt? Erre ebben a Kommentárban csak nagyon kevés utalás történik.

A Dante-értelmezések egyik sarokpontja, hogy ez a képzelet szülte gyönyörü költemény egy allegória, azaz a hívő ember pokoljárása utáni megtisztulása, hogy Isten színe elé kerüljön a mennyországban, vagy az evilági hús-vér ember története, aki szeretné elérni az igazi, földi és mennyei boldogságot. Ebben a kérdésben jelentősen megoszlik a hazai dantisztika is, de mindkettőnek vannak hívei. Ebben a Kommentárban, amelyben általában túlsúlyba került az allegorikus és vallásos értelmezés, még ebben is lehet ilyen mondatokat találni: „a Pokol tájai semmiben sem különböznek az e világi tájaktól” (224.). Igaz, hiszen Dante ezt a hatalmas költeményt úgy írta, mint az utakon, patakparton vándorló számüzött ember, aki gyakran kért alamizsnát és bebocsátást egy kolostorba, ahol csak egy kis meg- 
nyugvást, békét kívánt magának. Ritkán adatott meg neki, hogy hosszabb ideig például Veronában vagy élete végén Ravennában álljon meg. Ahogyan minden szerző, úgy Dante is beleírta magát főmüvébe.

A Pokol teljes magyar kommentárja kivételes felkészültséget igényelt a szerzőktől. Az Isteni Színjáték talán legismertebb részének értelmezése, magyarázata alapvető anyagot szolgáltat az ezután keletkező, most már erre a Kommentárra épülö Lectura Dantisok számára. Így lehetőség nyílna arra, hogy a külföldi példák mintájára Dante müvét a szélesebb olvasóközönség számára is befogadhatóvá lehetne tenni úgy, hogy egy-egy énekböl felolvasás után értelmezést és magyarázatot adna egy-egy Dante-kutató. A média a 2021-es Dante-év alatt erre alkalmas is lehetne. Így Dante nem maradna csak a szüken vett szakértők kutatási területe.

Impozáns ez a kötet, nemcsak tartalmát, tudományos erényeit, hanem külalakját tekintve is. Az ELTE Eötvös Kiadó kifejezetten szép, keményborítós kiadásban adta közre a Pokol-kommentárt a költő halála 700. évfordulója alkalmából. A jól szerkesztett és könnyen áttekinthető kötet megkönnyíti az olykor nem is olyan egyszerủen érthető fejtegetések olvasását. A magyar dantisztika jelentős mérföldköve ez a kötet.

(Dante Alighieri: Komédia I. Pokol. Kommentár [Szerk.: Kelemen János], Budapest: ELTE Eötvös Kiadó, 2019, 550 o.)

Szabó Tibor

filozófus, egyetemi tanár 